\title{
A Model of Factors Influencing Behavioral Intention to Use Internet Banking and The Moderating Role of Anxiety: Evidence from Vietnam
}

\author{
HA NAM KHANH GIAO ${ }^{1}$, BUI NHAT VUONG ${ }^{1, *}$, \\ DAO DUY TUNG ${ }^{2}$, TRAN NHU QUAN ${ }^{3}$ \\ ${ }^{1}$ Faculty of Air Transport, Vietnam Aviation Academy, Ho Chi Minh, VIETNAM \\ ${ }^{2}$ Graduate school of Management, Siam University, Bangkok, THAILAND \\ ${ }^{3}$ School of Business, International University-Vietnam National University HCMC, \\ VIETNAM
}

\begin{abstract}
Internet banking is becoming a new focus as the number of internet users and its benefits are increasing worldwide and its benefits. However, the degree of intent to use internet banking is still a question of interest. Thus, the purpose of this paper is to investigate the factors affecting attitude and behavioral intention to use internet banking in Viet Nam, as well as the moderating role of anxiety, will be examined. Totally, 584 questionnaires were collected for the final analysis. The results from the partial least squares structural equation modeling (PLS-SEM) using the SmartPLS 3.0 program showed that facilitating condition, performance expectancy, social influence, perceived credibility, and effort expectancy had a positive impact on attitude and behavioral intention to use internet banking. Besides, anxiety decreased behavioral intention and it also dampened the positive relationship between attitude and behavioral intention. The findings of this study could help banks to improve their service to attract more users. Besides, the use of internet banking could reduce the frequency to a bank that indirectly reduces costs.
\end{abstract}

Keywords: anxiety, facilitating condition, performance expectancy, social influence, perceived credibility, and effort expectancy

Received: April 15, 2020. Revised: May 20, 2020. Accepted: May 27, 2020

\section{Introduction}

Internet banking is an innovative service, which has been perpetuated by the development and diffusion of internet communication technology [1]. Internet banking services not only allow customers to carry out a range of banking activities such as managing bank accounts and transactions without leaving their desks [2], but also a very cost-efficient way for banks to provide their customer services [3]. Internet banking offers customers the advantages of lower costs, location, and time convenience, ease, and speed of completing transactions. As a one percent increase in the retention of Internet banking acceptance will typically bring an 18 percent reduction in operating cost [4], indifference towards consumers' adoption of Internet banking services may result in a big loss to the financial institutions. Therefore, the development of internet banking services is most important in bank management.

Internet banking plays a significant role in the banking industry. According to Myrtidis and Weerakkody [5], the implementation of information technology and communication networking has brought about a revolution in the functioning of the banks and the financial institutions. The transition to electronic banking has, therefore, become a necessity for banks as it offers major opportunities in terms of competitive advantage and it also allows banks to develop a stronger and more durable business relationship with its customers.

However, despite the numerous benefits, the acceptance of internet banking in Vietnam is relatively low when comparing to the West and the United States. In the Asian region, most studies concentrated on developed Asian countries than developing countries like Vietnam in the last twenty years. Thus, understanding the reason for acceptance or nonacceptance of new technologies by people is one of the greatest challenges. Hence, there is a necessity to research about the behavioral 
intention to use internet banking in Viet Nam. That is also the motivation for developing this research. Therefore, this study aims to find out which factors influencing attitude and behavioral intention to use internet banking in Viet Nam. Additionally, the moderating role of anxiety will be examined as well. These issues are important because the results help banks with marketing strategies encourage customers to use Internet banking in the future.

\section{Literature Review}

\subsection{Theoretical foundation}

The technology acceptance literature documents a rich collection of models and theories that could be used to explain the adoption of information technology innovations [6]. To understand technology adoption, Venkatesh, et al. [6] developed the Unified Theory of Acceptance and Use of Technology (UTAUT). Venkatesh, et al. [6] derived four main determinants of behavioral intention and usage as performance expectancy, effort expectancy, and social influence. Besides, the empirical results of the UTAUT model showed that it accounts for $70 \%$ of the variance in the usage intention, which makes it supersede other antecedent models of UTAUT. UTAUT model's four key constructs (performance expectancy, effort expectancy, social influence, and facilitating conditions) are direct determinants of usage intention and behavioral intention.

\subsection{Behavioral intention to use internet banking}

Consumers' self-reported intentions are measured similarly in many other studies. Warshaw and Davis [7] defined intention to be "the degree to which a person has formulated conscious plans to perform or not to perform some specified future behavior". Behavioral intention to use in this study is defined in a rather similar way as in previous studies as "the individual's likelihood of using internet banking service" [6]. The prediction of intention has interested scientists for a long time. As in many other acceptance papers in the field, this study also assumes that behavioral intention will have a positive effect on system usage in the future.

\section{Hypothesis development}

\subsection{Attitude and behavioral intention to use internet banking}

Attitude toward the behavior is defined "as the individual's positive or negative feelings about performing a behavior" [8]. Taylor and Todd [9] stated that attitude towards usage reflects feelings of favorableness or unavoidableness towards using the technology. They also asserted that behavior is a direct function of behavioral intention and this behavioral intention is constituted by one's attitude. Besides, Vuong, et al. [1] demonstrated the impact of attitude on the intention to use mobile banking. Hence, based on the above discussions, this study shows the following hypothesis:

Hypothesis $H_{1}$ : Attitude positively relates to behavioral intention to use Internet banking.

\subsection{Facilitating conditions}

Facilitating conditions are the degree to which an individual believes that an organizational and technical infrastructure exists to support the use of the system [6]. In other words, facilitating conditions refers to the availability of resources such as written documents and technological infrastructure in supporting the use of new technology. In order to encourage internet banking use, facilitating conditions should present includes ease of access, navigation, and searching, more so when proper guidance is provided. Other conditions include costs and other resources associated with such use, and the prior knowledge that users must have before they could use internet marketing. Facilitating conditions and habits are also good predictors of attitude and behavior intention to use internet banking. Therefore, the following hypotheses are proposed:

Hypothesis $\mathrm{H}_{2}$ : Facilitating conditions have a positive influence on attitude toward using internet banking.

Hypothesis $\mathrm{H}_{3}$ : Facilitating conditions have a positive influence on behavior intention to use Internet banking.

\subsection{Social influence}

Social influence is "the degree to which an individual perceives that important others believe he or she should use the new system" [6]. Social influence is understood as the way that other people influence one's beliefs, feelings, and behavior [10]. Particularly the people who are important to an individual play an important role in the considerations of whether or not to use a new technological system. Also, other reference groups such as organizations or the media have an influence on social situations [9]. Bagozzi and Dholakia [11] 
stated that personal connections such as family members, supervisors, professors, peers, the university administrator and environment, and even the online community have been identified to facilitate the behavior of users towards intention to use internet banking. The previous studies also asserted social influence impacted on attitude and behavioral intention to use internet Banking [e.g., 12]. Therefore, the following hypotheses are proposed:

Hypothesis $\mathrm{H}_{4}$ : Social influence has a positive influence on attitude toward using internet banking.

Hypothesis $H_{5}$ : Social influence has a positive influence on behavioral intention to use Internet banking.

\subsection{Performance expectancy}

Performance expectancy can be defined "as the extent to which an individual believes that using the system will help them achieves highperformance work" [13]. It reflects the assessment of the benefits received when initiatives are accepted or use. Internet banking offers many benefits to customers as customers can perform many financial transactions. Moreover, accessibility is an important aspect associated with the performance expectancy of internet banking [14]. The internet enables users to visit an online banking website at any time and from any location more easily and efficiently. In comparison with traditional banking, internet banking is able to reach far more people and keep away people from waiting in lines. So, customers feel the work efficiency improved by time-saving and convenience. In other words, this research expects customers aware of internet banking provided to these utilities, customers have a positive attitude with this technology. In this study's context, performance expectancy refers to the belief that by using internet marketing will help users gain benefits such as increased productivity, efficiency, and time-saving. The previous studies also confirmed that performance expectancy was a significant positive relationship with attitude and behavioral intention to use internet banking [e.g., 13]. Thus, the following hypotheses are proposed:

Hypothesis $H_{6}$ : Performance expectancy has a positive influence on attitude toward using internet banking.

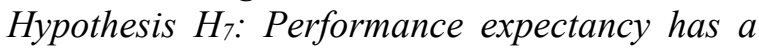
positive influence on behavioral intention to use Internet banking.

\subsection{Effort expectancy}

Effort expectancy is the degree to which a person believes that using a particular system would be effortless physical and spiritual [15]. Effort expectancy is expected to influence the intention to use the system in the future. Effort expectancy is simply the consumer's perception of how easy or hard it is to use the system. If it is easy it means that using the system would be effortless. The interaction required by the system is understandable, and the consumers see themselves becoming skillful at using the system. Innovations can be difficult to use at first, but if people believe that they will easily get the system to do what they want to do, it can be considered effortless. Raman and Don [14] affirmed effort expectancy as a key driver of growth in attitude and internet banking acceptance. Therefore, the following hypotheses are suggested:

Hypothesis $H_{8}$ : Effort expectancy has a positive influence on attitude toward using internet banking.

Hypothesis $H_{9}$ : Effort expectancy has a positive influence on behavioral intention to use Internet banking.

\subsection{Perceived credibility}

Perceived credibility is defined "as the degree to which an individual believes an internet banking system as trustworthy and secure" [1]. An increase in the perceived credibility will subsequently improve users' internet banking acceptance. Therefore, creating customer trust is an essential way to retain existing bank customers [16]. Also, Vuong, et al. [1] empirically concluded that perceived credibility significantly affected attitude and human intention to use mobile banking. Accordingly, this study hypothesizes:

Hypothesis $H_{10}$ : Perceived credibility has a positive influence on attitude toward using internet banking.

Hypothesis $H_{11}$ : Perceived credibility has a positive influence on behavioral intention to use Internet banking.

\subsection{Anxiety}

Anxiety is "the feeling of nervousness when it comes to using new technology" [17]. Similarly, Anxiety is a concept most countries also reaffirmed behavior trends using computers. In the context of computer usage, technology 
anxiety is shown to decrease effort expectancy and subsequent behavior intention to use [18]. Anxiety is defined as the degree to which an individual becomes anxious when it comes to using the internet banking system [6]. Anxiety is fear of stolen passwords or mistakes when using online banking services. Giao, et al. [16] stated that individuals with little or no computer and internet experience have a higher level of anxieties than experienced computer and Internet users.

This study argues that internet service anxiety affects the behavioral intention to use internet banking services. Anxiety can be seen as a negative emotional reaction towards performing a behavior (e.g. using an internet banking service). A significant body of literature has highlighted the importance of technology anxiety by demonstrating its influence on intention. However, users generally overcome their initial anxious feelings and develop favorable perceptions as they become familiar with the technologies.

When individuals have less experience with new technology, they are forced to rely upon their general beliefs regarding technologies and technology use and, therefore, their attitude may reflect a high degree of anxiety. This study expects that anxiety will have a significant negative on behavioral intention to use Internet banking. At the same time, it will also moderate the positive relationship between attitude and behavioral intention to use Internet banking. Therefore, the following hypotheses are identified as follow (Figure 1):

Hypothesis $H_{12}$ : Anxiety has a negative effect on behavioral intention to use Internet banking.

Hypothesis $H_{13}$ : Anxiety moderates the effect of attitude on behavioral intention to use Internet banking. This positive relationship will be lower for customers who have a high degree of anxiety.

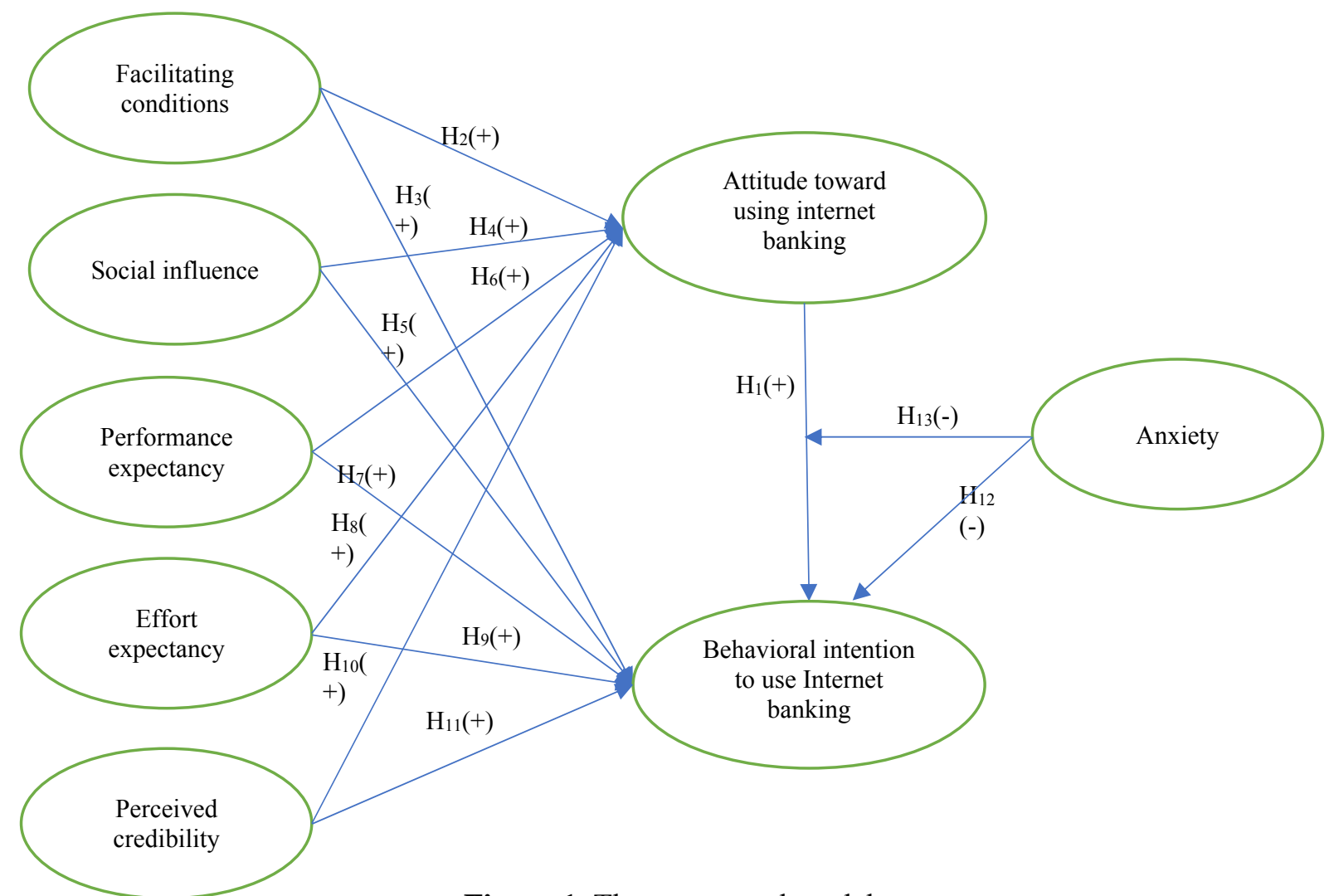

Figure 1. The conceptual model

\section{Methods}

All the variables in the model were measured with multiple items, which were developed by other researchers, to adequately capture the domain of constructs. Items are measured on five-point Likert scale where $1=$ strongly disagree, $2=$ disagree, $3=$ neutral, $4=$ agree, $5=$ strongly agree.

The questionnaire using a five-point Likert scale was to collect the data for the factors of the research model. Items select for 
the factors are mostly adapted from previous studies to ensure content validity. The survey questionnaire was originally designed in English and then translated into Vietnamese by the researcher with the support of some English experts and banking experts. To conduct qualitative research, the Vietnamese version of the survey questionnaire was pre-tested using indepth interviews with some customers who have knowledge of internet banking services. The indepth interviews were conducted with 10 respondents ( 2 banking experts and 8 customers for answering) to ensure that the final questions would be well understood and valuable in measuring observed variables before launching the main survey. The detailed questionnaire was shown to interviews for checking their understanding. During the interview, the author also wanted to find out if the chosen measurement scale was suitable for researching Viet Nam. All the comments from the interviewees were gathered to modify the measurement scale. Based on the feedback of respondents, the survey questionnaire was slightly modified to make it clearer and more understandable. The results of the pilot test proved the good design of questionnaires, and they were used in the main survey.

Table 1. Demographic characteristic

\begin{tabular}{|c|c|c|c|}
\hline \multicolumn{2}{|r|}{$\mathrm{N}=584$} & Frequency & Percent \\
\hline \multirow{2}{*}{ Gender } & Female & 333 & 57.0 \\
\hline & Male & 251 & 43.0 \\
\hline \multirow{4}{*}{ Age group } & $18-25$ & 91 & 15.6 \\
\hline & $26-35$ & 277 & 47.4 \\
\hline & $31-45$ & 139 & 23.8 \\
\hline & $>45$ & 77 & 13.2 \\
\hline \multirow{4}{*}{ Income } & $<5$ million $\mathrm{VND}$ & 35 & 6.0 \\
\hline & 5-10 million VND & 239 & 40.9 \\
\hline & $\begin{array}{l}\text { 10-15 million } \\
\text { VND }\end{array}$ & 188 & 32.2 \\
\hline & $>15$ million VND & 122 & 20.9 \\
\hline \multirow{4}{*}{ Education } & Under college & 117 & 20.0 \\
\hline & College & 112 & 19.2 \\
\hline & University & 336 & 57.5 \\
\hline & Postgraduate & 19 & 3.3 \\
\hline
\end{tabular}

Table 2. Construct reliability and validity

\begin{tabular}{lllllrlrrrr}
\hline & CA & AVE & FC & \multicolumn{1}{c}{ SI } & PE & EE & PC & \multicolumn{1}{l}{ AN } & \multicolumn{1}{l}{ AT } & BI \\
\hline FC & 0.862 & 0.783 & $(0.885)$ & 0.345 & 0.260 & 0.479 & 0.502 & -0.496 & 0.317 & 0.070 \\
SI & 0.832 & 0.748 & & $(0.865)$ & 0.338 & 0.344 & 0.489 & -0.425 & 0.361 & 0.019 \\
PE & 0.876 & 0.728 & & & $(0.853)$ & 0.290 & 0.494 & -0.480 & 0.236 & -0.034 \\
EE & 0.862 & 0.707 & & & & $(0.841)$ & 0.501 & -0.459 & 0.370 & 0.100 \\
PC & 0.837 & 0.860 & & & & & $(0.927)$ & -0.830 & 0.417 & 0.158 \\
AN & 0.817 & 0.845 & & & & & & $(0.919)$ & -0.388 & -0.142 \\
AT & 0.843 & 0.611 & & & & & & & $(0.782)$ & -0.006 \\
BI & 0.868 & 0.706 & & & & & & & & $(0.840)$ \\
\hline
\end{tabular}

Notes:

$\mathrm{CA}=$ Cronbach's Alpha; AVE = Average Variance Extracted; FC = Facilitating Conditions; $\mathrm{SI}=$ Social Influence; $\mathrm{PE}$ $=$ Performance Expectancy; EE $=$ Effort expectancy; $\mathrm{PC}=$ Perceived Credibility; $\mathrm{AN}=$ Anxiety; $\mathrm{AT}=\mathrm{Attitude} ; \mathrm{BI}=$ Behavioral Intention. Square roots of AVE of latent constructs were shown in the parentheses. 
Convergent validity is the amount of variance between two or more items that agree when measuring similar constructs and is calculated using factor loadings. Vuong and Giao [21] stated that convergent validity will be suitable when the factor loadings are above 0.5. In Table 3, the statistical results showed that all factor loadings were more than the threshold of 0.5. For example, the minimum factor loading was 0.601 (Table 3). Besides, convergent validity will be confirmed when the average variance extracted (AVE) for each of the latent variables is greater than 0.5 [22]. As shown in Table 3 below, AVE values were reported for each of the variables ranging from 0.611 to 0.860 . Therefore, all constructs showed good convergent validity.

Table 3. The factor loadings

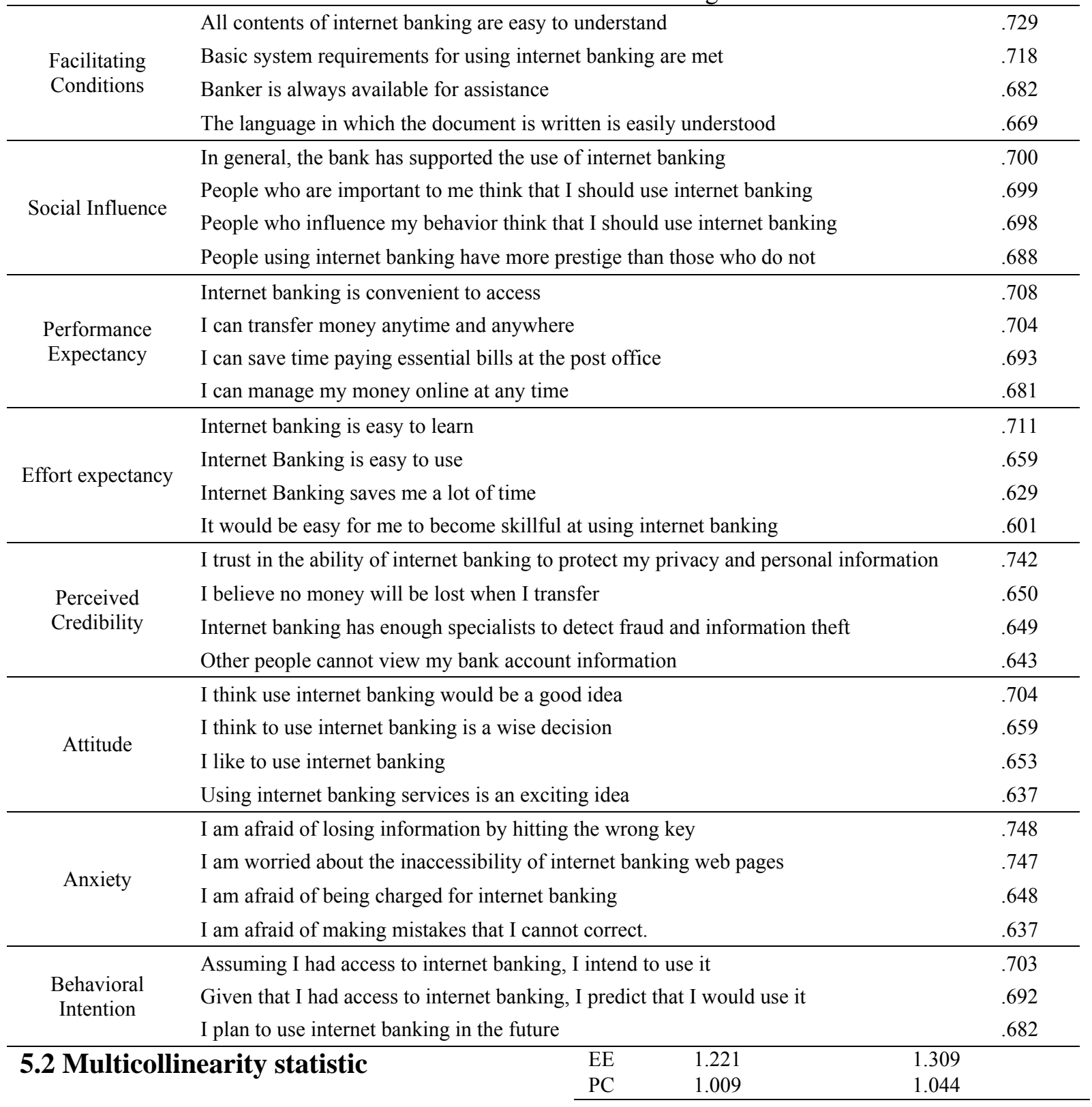

Table 4. Multicollinearity statistic

\begin{tabular}{lcc}
\hline & Attitude & Behavioral Intention \\
\hline FC & 1.224 & 1.512 \\
SI & 1.309 & 1.363 \\
PE & 1.174 & 1.360 \\
AT & & 1.501 \\
AN & & 1.858
\end{tabular}

Finally, multicollinearity was assessed for all of the constructs. The variance inflation factor (VIF) indicator was suggested to measure multicollinearity issues. The VIF value should be less than a 5.00 tolerance level [23]. As 
shown in Table 4, the maximum inner VIF value of constructs was 1.858. Therefore, the collinearity of the latent variables was not a concern.

\subsection{Hypothesis testing}

Results from the PLS-SEM analysis are shown in Figure 2. Standardized path coefficients and $\mathrm{p}$-values are reported. The findings are presented as follows:



Figure 2. The structural model

Table 5. Results of the relationship checking of the model's constructs.

\begin{tabular}{|c|c|c|c|c|c|c|c|c|}
\hline \multirow{2}{*}{$\begin{array}{c}\text { Hypothesis } \\
\mathrm{H}_{1}\end{array}$} & \multicolumn{3}{|c|}{ Relationship } & \multirow{2}{*}{$\begin{array}{c}\begin{array}{c}\text { Path } \\
\text { Coefficient }\end{array} \\
0.095\end{array}$} & \multirow{2}{*}{$\begin{array}{c}\begin{array}{c}\text { Standard } \\
\text { Deviation }\end{array} \\
0.025\end{array}$} & \multirow{2}{*}{$\frac{\text { T-Statistics }}{3.831}$} & \multirow{2}{*}{$\begin{array}{c}\text { P-Values } \\
0.000\end{array}$} & \multirow{2}{*}{$\begin{array}{c}\text { Result } \\
\text { Supported }\end{array}$} \\
\hline & AT & $\rightarrow$ & BI & & & & & \\
\hline $\mathrm{H}_{2}$ & $\mathrm{FC}$ & $\rightarrow$ & AT & 0.341 & 0.035 & 9.887 & 0.000 & Supported \\
\hline $\mathrm{H}_{3}$ & $\mathrm{FC}$ & $\rightarrow$ & BI & 0.055 & 0.020 & 2.783 & 0.006 & Supported \\
\hline $\mathrm{H}_{4}$ & SI & $\rightarrow$ & AT & 0.114 & 0.040 & 2.868 & 0.004 & Supported \\
\hline $\mathrm{H}_{5}$ & SI & $\rightarrow$ & BI & 0.106 & 0.019 & 5.558 & 0.000 & Supported \\
\hline $\mathrm{H}_{6}$ & $\mathrm{PE}$ & $\rightarrow$ & AT & 0.192 & 0.039 & 4.989 & 0.000 & Supported \\
\hline $\mathrm{H}_{7}$ & $\mathrm{PE}$ & $\rightarrow$ & $\mathrm{BI}$ & 0.051 & 0.021 & 2.475 & 0.014 & Supported \\
\hline $\mathrm{H}_{8}$ & $\mathrm{EE}$ & $\rightarrow$ & AT & 0.079 & 0.034 & 2.287 & 0.023 & Supported \\
\hline $\mathrm{H}_{9}$ & $\mathrm{EE}$ & $\rightarrow$ & BI & 0.055 & 0.021 & 2.656 & 0.008 & Supported \\
\hline $\mathrm{H}_{10}$ & $\mathrm{PC}$ & $\rightarrow$ & $\mathrm{AT}$ & 0.120 & 0.040 & 2.974 & 0.003 & Supported \\
\hline $\mathrm{H}_{11}$ & $\mathrm{PC}$ & $\rightarrow$ & $\mathrm{BI}$ & 0.091 & 0.022 & 4.108 & 0.000 & Supported \\
\hline $\mathrm{H}_{12}$ & $\mathrm{AN}$ & $\rightarrow$ & $\mathrm{BI}$ & -0.634 & 0.025 & 25.521 & 0.000 & Supported \\
\hline $\mathrm{H}_{13}$ & ME & $\rightarrow$ & BI & -0.053 & 0.023 & 2.281 & 0.023 & Supported \\
\hline
\end{tabular}

$\mathrm{FC}=$ Facilitating Conditions; $\mathrm{SI}=$ Social Influence; $\mathrm{PE}=$ Performance Expectancy; $\mathrm{EE}=$ Effort expectancy; $\mathrm{PC}=$ Perceived Credibility; AN = Anxiety; AT = Attitude; BI = Behavioral Intention; ME = Moderating effect $1=\mathrm{AT}^{*} \mathrm{AN}$.

Based on results from table coefficients (Table attitude and behavioral intention to use Internet 5), the authors could confirm that facilitating conditions, social influence, performance expectancy, effort expectancy, and perceived credibility had a positive relationship with banking due to all p-values of these variables were less 0.05 . Therefore, Hypothesis $\mathrm{H}_{1}, \mathrm{H}_{2}$, $\mathrm{H}_{3}, \mathrm{H}_{4}, \mathrm{H}_{5}, \mathrm{H}_{6}, \mathrm{H}_{7}, \mathrm{H}_{8}, \mathrm{H}_{9}, \mathrm{H}_{10}, \mathrm{H}_{11}$ were supported. 


\subsection{The moderating role of anxiety}

Hypothesis H12: The standardized coefficient beta of anxiety on behavioral intention to use Internet banking is -0.634 , and the p-value was 0.000 which was less 0.05 (Table 5). There was a negative impact of anxiety on behavioral intention. Therefore, Hypothesis $\mathrm{H}_{12}$ was supported.

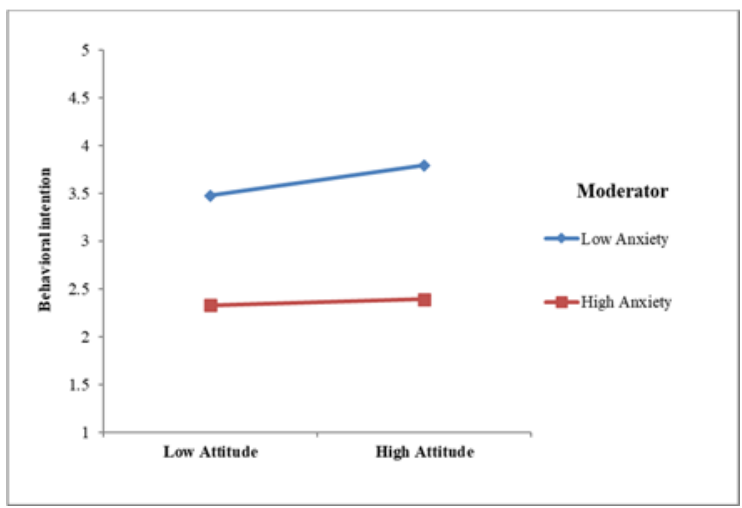

Figure 3. The moderating effect of anxiety

Hypothesis 13 predicted that anxiety would moderate the relationship between attitude and behavioral intention to use Internet banking. The study showed that the moderating effect 1 of the interaction between attitude and anxiety on behavioral intention was negative and statistically significant (beta coefficient $=-0.053$ and $p$-value $=0.023$ ) (Figure 2). This finding proposed that anxiety negatively moderated the relationship between attitude and behavioral intention to use Internet banking. In other words, the positive relationship between AT and BI was lower for customers who had a high degree of anxiety. (Figure 3). Therefore, Hypothesis 13 was supported.

Generally, anxiety had the strongest negative relationship with behavioral intention with a beta coefficient of -0.633 , and effort expectancy had the lowest positive impact on behavioral intention to use internet banking with a beta coefficient of 0.229 .

\subsection{Model Fit}

The coefficient of determination $\left(\mathrm{R}^{2}\right)$ is a measure of the model's predictive power. Its value ranges from 0 to 1 . The high $R^{2}$ coefficient also reveals that the values of the variables can be well predicted by the PLS path model [2326]. The $R^{2}$ value for the behavioral intention was 0.612 which indicated that 61.2 of the total variation of behavioral intention may be explained by six variables such as facilitating conditions, social influence, performance expectancy, effort expectancy, perceived credibility, and anxiety. Moreover, $\mathrm{R}^{2}$ values and the effect for endogenous latent variables in behavioral sciences can be assessed as 0.26 (large effect), 0.13 (moderate effect), and 0.02 (weak effect). Because $\mathrm{R}^{2}$ values for the turnover intention were greater than 0.26 , the model of this study proved the model-data fit.

\section{Conclusion and implications}

\subsection{Conclusion}

The proposed conceptual model of this study proposed five independent factors affecting attitude and behavioral intention to use internet banking, which is facilitating conditions, social influence, performance expectancy, effort expectancy, perceived credibility. Besides, the moderating role of anxiety is also examined.

PLS-SEM analysis indicated that anxiety is the most negatively affecting behavioral intention to use internet banking with the highest standardized beta of -0.634 . It means that any changing of anxiety would most affect behavioral intention than others. Then the descending order of relation with behavioral intention is facilitating condition $(\beta=0.491)$, performance expectancy $(\beta=0.338)$, social influence $(\beta=0.315)$, perceived credibility $(\beta=0.306)$, and effort expectancy $(\beta=0.229)$.

\subsection{Implications}

Based on findings of this research, this study could provide practical contributions to the banking industry, particularly to the leaders of the commercial banks, and the marketing managers who have the intention to expand on behavioral intention to use internet banking in Vietnam.

First, anxiety negatively affected the trend of using internet banking and it also dampened the positive relationship between attitude and behavioral intention. Respondents have opinions anxiety about using internet banking. Some respondents exhibit high anxieties of being charged for internet banking, inaccessibility of internet banking web pages. Hence, website quality is considered an important feature of a bank's web design. When customers have high anxiety levels about passwords can be stolen or errors in financial transactions can occur, this will negatively impact the trend to use their internet banking. Hence, banks might want to consider free charge 
internet training to novice users periodically.

Second, facilitating conditions is the second most important motivator of internet banking. It is important for users to obtain advice from bank personnel before service registration to prevent unintentionally subscription to internet banking that is inappropriate or unnecessary. To help customers overcome obstacles in using internet banking, banks should provide responsive and interactive consumer support in the forms of email, online chat, call center, or even face-to-face assistance. A collection of documents relating to the use and application of internet banking should also be made available on the official web site of banks for users' easy reference. Besides, banks could also consider giving free foundation tutorials to the public at schools, bank branches, or shopping complexes.

Third, performance expectancy is the third most important motivator of using internet banking services. Banks should increase the benefits of internet banking by launching more innovative banking products and services tailored to the needs of consumers. For example, pay tax and summons through internet banking. Also, they could add third party services such as insurance, unit trust, and purchase of stocks to provide a one-stop financial service.

Fourth, social influence had the fourth strong effect on behavioral intention to use internet banking. As a highly social society, the Vietnamese are influenced by others in their daily life and also when using internet banking. Thus, banks' efforts to advertise for the benefits of Internet banking can be amplified through the social influence on people. On the other hand, it emphasizes consumers' everyday behavior in a social and cultural environment, the role of technology within it, and factors that influence the practices of consumers.

Fifth, perceived credibility had the fifth strong effect on behavioral intention to use internet banking. Customers are generally more concerned with the security of internet banking compared with traditional banking services. Therefore, industry-wide best security standards should be developed and made mandatory for all domestic banks to comply with. At a minimum, two-factor authentication should be implemented, with the use of username and password as the first authentication factor and the use of transaction authorization code (onetime code), identity card or international passport number as the second authentication factor. To achieve better security, banks might want to consider adopting three-factor authentication which includes the use of biometric such as iris or thumbprint recognition for user identification. Security might be important for banks to develop a marketing strategy for Internet banking. There is a need to upgrade the banks' security system.

Finally, effort expectancy had the lowest effect on behavioral intention to use internet banking. Time management is important for working parents and any technology that could help them perform more efficiently will be highly regarded and quickly accepted. Internet banking allows busy working parents to quickly complete their banking tasks so that they have more time to cater to the needs of their families. Therefore, the time - saving benefit of using internet banking is worth emphasizing.

\section{Limitations and recommendations for future research}

This study still exposes some limitations, based on that future research can be developed. Firstly, the sample is selected conveniently and just from some banks in Vietnam, so it is not representative of the population. Thus, it is suggested sample size should be increased with a probability sampling method in the future study to generate more reliable results.

Secondly, future investigations should combine the impact of control variables such as gender, education, income, and age on behavioral intention to use internet banking. Lastly, the study on behavioral intentions can be extended to corporate customers. Comparison can be made between individual customers and corporate customers to identify factors influencing their adoption decisions.

\section{References}

[1] Vuong, B.N., et al. An empirical analysis of mobile banking adoption in Vietnam. Gestão e Sociedade 2020, 14, 3365-3393, https://doi.org/10.21171/ges.v14i37.3078.

[2] Weir, C.S., et al. On the role of metaphor and language in design of third party payments in eBanking: Usability and quality. International Journal of HumanComputer Studies 2006, 64, 770-784.

[3] Yakhlef, A. Does the Internet compete with or complementbricks and mortar bank branches? International Journal of Retail \& Distribution Management 2001, 29, 272- 
281.

[4] Bhattacherjee, A. Understanding information systems continuance: An expectation-confirmation model. MIS Quarterly 2001, 25, 351-370.

[5] Myrtidis, A.; Weerakkody, V. A study of information systems investment evaluation in the Greek banking sector. Information Technology for Development 2008, 14, 1130.

[6] Venkatesh, V., et al. User acceptance of information technology: Toward a unified view. MIS Quarterly 2003, 27, 425-478.

[7] Warshaw, P.R.; Davis, F.D. The accuracy of behavioral intention versus behavioral expectation for predicting behavioral goals. The Journal of Psychology 1985, 119, 599602.

[8] Ajzen, I. The theory of planned behavior. Organizational Behavior and Human Decision Processes 1991, 50, 179-211.

[9] Taylor, S.; Todd, P.A. Understanding information technology usage: A test of competing models. Information Systems Research 1995, 6, 144-176.

[10] Hooi Ting, D., et al. Dependency on smartphone and the impact on purchase behaviour. Young Consumers 2011, 12, 193-203.

[11] Bagozzi, R.P.; Dholakia, U.M. Intentional social action in virtual communities. Journal of Interactive Marketing 2002, 16 , 2-21.

[12] Khan, A.P., et al. Factors influencing consumer intentions to adopt online banking in Malaysia. Business \& Economic Review 2017, 9, 101-134.

[13] Chao, C.-M. Factors determining the behavioral intention to use mobile learning: An application and extension of the UTAUT model. Frontiers in psychology 2019, 10, 1652-1652.

[14] Raman, A.; Don, Y. Preservice teachers' acceptance of learning management software: An application of the UTAUT2 model. International Education Studies 2013, 6, 157-164.

[15] Davis, F.D. Perceived usefulness, perceived ease of use, and user acceptance of information technology. MIS Quarterly 1989, 13, 319-340.

[16] Giao, H.N.K., et al. The influence of website quality on consumer's e-loyalty through the mediating role of e-trust and esatisfaction: An evidence from online shopping in Vietnam. Uncertain Supply Chain Management 2020, 8, 351-370, https://doi.org/10.5257/j.uscm.2019.11.004.

[17] Liao, Z.; Cheung, M.T. Internet-based ebanking and consumer attitudes: An empirical study. Information \& Management 2002, 39, 283-295.

[18] Venkatesh, V.; Bala, H. Technology acceptance model 3 and a research agenda on interventions. Decision Sciences 2008, 39, 273-315.

[19] Vuong, B.N.; Suntrayuth, S. The impact of human resource management practices on employee engagement and moderating role of gender and marital status: An evidence from the Vietnamese banking industry. Management Science Letters 2020, 10, 1633-1648, https://doi.org/10.5267/j.msl.2019.12.003.

[20] Giao, H.N.K., et al. The effect of emotional intelligence on turnover intention and the moderating role of perceived organizational support: Evidence from the banking industry of Vietnam. Sustainability 2020, 12 ,

1857 , https://doi.org/10.3390/su12051857.

[21] Vuong, B.N.; Giao, H.N.K. The Impact of Perceived Brand Globalness on Consumers' Purchase Intention and the Moderating Role of Consumer Ethnocentrism: An Evidence from Vietnam. Journal of International Consumer Marketing 2020, 32, 47-68, https://doi.org/10.1080/08961530.2019.161 9115.

[22] Giao, H.N.K., et al. A model of organizational culture for enhancing organizational commitment in telecom industry: Evidence from vietnam. WSEAS Transactions on Business and Economics 2020, 17, 215-224, https://doi.org/10.37394/23207.2020.17.23.

[23] Giao, H.N.K.; Vuong, B.N. Giáo trình cao hoc phuong pháp nghiên cúu khoa hoc trong kinh doanh cập nhật SmartPLS; Nhà Xuất Bản Tài Chính: TP. Hồ Chí Minh, 2019.

[24] Vuong, B.N. Ảnh hưởng của các yếu tố chất lượng cuộc sống nơi làm việc đến sự gắn kết với tổ chức của nhân viên ngân hàng thương mại cổ phần Á Châu tại TP. HCM. Huflit Journal of Science 2017, 4, 37-47.

[25] Giao, H.N.K.; Vương, B.N. Ảnh hưởng của các yếu tố văn hóa doanh nghiệp đến sự 
gắn bó của nhân viên với tổ chức tại Công ty $\mathrm{CP}$ CMC Telecom Thành Phố Hồ Chí Minh. Tạp chi Kinh tế - Kỹ thuật 2016, 13, 87-101.

[26] Vuong, B.N.; Arthachinda, P. The effect of transformational leadership on job performance through the mediation of job satisfaction: The case of Vietnamese stateowned organizations. The Korean Association For Public Administration 2019, 161, 519-548.

Creative Commons Attribution License 4.0

(Attribution 4.0 International, CC BY 4.0)

This article is published under the terms of the Creative Commons Attribution License 4.0

https://creativecommons.org/lice nses/by/4.0/deed.en_US 